УДК 346.32

DOI https://doi.org/10.32849/2663-5313/2019.6.12

\title{
Анна Бучинсъка,
}

канд. юрид. наук,

доцент кафедри правознавства

Житомирського начіонального агроекологічного університету

\section{ШІТРАФНІ САНКЦІЇ У СФЕРІ ГОСПОДАРЮВАННЯ ЗА ЗАКОНОДАВСТВОМ УКРАЇНИ ТА ПОЛЬЩ}

У статті досліджуються нормативно-правові і практичні аспекти застосування штрафних санкиї у сфері господарювання за законодавством України та Польші. Проведений аналіз дає підстави стверджувати, що і в українському, і в польському законодавстві за невиконання або неналежне виконання господарських зобов'язань застосовуються штрафні санкиії. Зроблено висновок щодо схожості підходів у законодавстві двох держав щодо застосування штрафних санкиій, до яких віднесено штраф і пеню, за винятком неустойки, яка передбачена лише в законодавстві Украйни.

Ключові слова: неустойка, штраф, пеня, зовнішньоекономічний договір, невиконання та неналежне виконання господарських зобов'язань.

Постановка проблеми. Одним із перших законодавчих актів, який проголошував свободу здійснення господарської діяльності у зовнішніх зносинах, був Закон України «Про зовнішньоекономічну діяльність» від 16.04.1991, який відкрив можливість суб'єктам господарювання вступати в зовнішньоекономічні відносини шляхом укладення зовнішньоекономічних договорів. Підписання Україною Угоди про асоціацію з СС ще більш поглибило інтеграційні процеси $з$ державами - членами $С \mathrm{C}$, особливо у сфері економічної співпраці. Польща не тільки є державою - членом ЄС, але й нашим сусідом, з яким Україна постійно підтримує тісні економічні зв'язки, в тому числі торгівельні.

Огляд публікацій. Необхідно зазначити, що в український юридичній літературі не проведено жодних досліджень щодо застосування господарських санкції в польському праві. А оскільки, як зазначено вище, Україна співпрацює з Польщею в різних напрямах, у тому числі в економічній сфеpi, варто висвітлити даний аспект насамперед у практичному аспекті, що має допомогти уникнути непорозумінь під час укладення зовнішньоекономічних договорів між суб'єктами господарювання України та Польщі. Це і є метою статті.

Виклад основного матеріалу. Укладаючи господарський договір, у тому числі зовнішньоекономічний, кожна зі сторін розраховує на те, що він буде виконаний своєчасно, належним чином, наприклад, що поставлений товар буде якісний, об'єкт своєчасно зданий в експлуатацію. На жаль, досить часто виникає ситуація, коли підрядник із різних причин не виконує своїх зобов'язань згідно 3 договором, або постачальник здійснює поставку невідповідного товару, чи покупець несвоєчасно проводить розрахунки. Саме в такій ситуації кожна зі сторін намагається найкращим чином захистити свій юридичний інтерес, передбачивши господарські санкції ще на етапі укладення договору.

Серед господарських санкцій важливу роль відіграють штрафні санкції, застосування яких передбачено і в разі укладення зовнішньоекономічних договорів. Зокрема наказом Міністерства економіки та з питань європейської інтеграції України № 201 від 06.09.2001 затверджено Положення про форму зовнішньоекономічних договорів (контрактів), яким визначено порядок застосування штрафних санкцій у зв'язку з невиконанням або неналежним виконанням одним із контрагентів своїх зобов'язань. При цьому мають бути чітко визначені розміри штрафних санкцій (у відсотках від вартості недопоставленого товару (робіт, послуг) або суми неоплачених коштів, строки виплати штрафів від якого терміну вони встановлюються та протягом якого часу діють, або їх граничний розмір) [1, п. 1.11].

Господарський кодекс України (далі - ГКУ) визначає штрафні санкції як господарські санкції у вигляді грошової суми (неустойка, штраф, пеня), яку учасник господарських відносин зобов'язаний сплатити у разі порушення ним правил здійснення господарської діяльності, невиконання або неналежного виконання господарського зобов'язання [2, ст. 230]. Аналіз положень ГКУ дає підстави стверджувати, що законодавець не сформулював самих понять 
«неустойка», «штраф», «пеня», що може викликати труднощі у їх застосуванні в господарському обігу. Натомість визначення цих понять дає Цивільний кодекс України. Зокрема, стаття 549 ЦКУ встановлює, що неустойкою (штрафом, пенею) $є$ грошова сума або інше майно, які боржник повинен передати кредиторові у разі порушення боржником зобов'язання. Штрафом $є$ неустойка, що обчислюється у відсотках від суми невиконаного або неналежно виконаного зобов'язання. Пенею є неустойка, що обчислюється у відсотках від суми несвоєчасно виконаного грошового зобов'язання за кожен день прострочення виконання [3].

У науковій літературі зазначено, що під штрафом, який може бути застосований у разі невиконання або неналежного виконання господарського зобов'язання необхідно розуміти грошову суму, розмір якої встановлюється нормативно-правовими актами або договором у твердій сумі, або у процентному відношенні до ціни всього договору чи невиконаної його частини, або у кратному розмірі до ціни договору чи вартості майна, що застосовується незалежно від збитків потерпілого та стягується одноразово [4, с. 38].

За загальним правилом, розмір штрафних санкцій передбачається законом чи договором. Пріоритет у визначенні розміру штрафних санкцій надається закону. Так, наприклад ч. 2 ст. 231 ГКУ встановлено розміри штрафних санкцій, якщо порушено господарське зобов'язання, в якому хоча б одна сторона є суб'єктом господарювання, що належить до державного сектора економіки, або порушення пов'язане з виконанням державного контракту, або виконання зобов'язання фінансується за рахунок Державного бюджету України чи за рахунок державного кредиту [2].

На думку науковців, на відміну від пені, передбаченої ЦКУ, дана штрафна санкція у господарських відносинах може застосовуватись як щодо грошових, так і щодо інших зобов'язань. Також пропонується під пенею розуміти грошову суму, яка встановлюється нормативно-правовими актами або договором за прострочення виконання господарських зобов'язань суб'єктом господарювання, обчислюється у відсотках, розмір стягнення якої є граничним та не може перевищувати подвійної облікової ставки НБУ за кожен день прострочки, період стягнення якої є граничним і не може перевищувати 6 місяців (п. 6 ст. 231, ст. 343 ГКУ та Закон України «Про несвоєчасне виконання грошових зобов'язань») [4, с. 38].

Розмір пені сторони визначають у договоpi самостійно, але він не може перевищувати визначеного Законом України «Про несвоєчасне виконання грошових зобов'язань» від 22.11.1996, тобто максимального розміру, встановленого як подвійна облікова ставка НБУ [5]. Такий граничний розмір пені, на думку деяких науковців, є заниженим [6, c. 14].

На практиці найбільше проблем може виникати у разі застосування такої штрафної санкції, як неустойка, яка одночасно являє собою міру відповідальності і спосіб забезпечення виконання зобов'язань. Вважається, що основне призначення неустойки виражається в стимулюванні боржника до належного виконання свого зобов'язання, а додаткове - в тому, що вона є невигідним наслідком для несправного боржника [4, с. 38]. Складність застосування такого виду штрафних санкцій пов'язана з відсутністю її визначення у ГКУ, а також відсутністю регулювання розміру неустойки, що може призвести до невиправдано високих іï розмірів.

Відповідно до ст. 233 ГКУ, у разі, якщо належні до сплати штрафні санкції надмірно великі порівняно зі збитками кредитора, суд має право зменшити розмір санкцій. При цьому повинно бути взято до уваги: ступінь виконання зобов'язання боржником; майновий стан сторін, які беруть участь у зобов'язанні; не лише майнові, але й інші інтереси сторін, що заслуговують на увагу [2].

Слід також зазначити, що на практиці реально стягнути штрафні санкції можливо тільки за рішенням суду і якщо їхній розмір визначений договором у межах чинного законодавства. Хоча, як зазначається в науковій літературі, перелік способів обчислення штрафних санкцій не $є$ вичерпним, оскільки, виходячи із загальнодозвільного принципу правового регулювання господарських відносин, сторони у договорі можуть передбачити й інші способи, якщо це не буде суперечити імперативним приписам закону [7, с. 390].

Таким чином, штрафні санкції застосовуються у вигляді грошової суми або іншого майна; підставою застосування штрафних санкцій є невиконання або неналежне виконання господарського зобов'язання; законом може бути визначений граничний розмір штрафних санкцій.

На відміну від українського законодавства, в якому діє Господарський кодекс України, господарське право Польщі не має кодифікованого акта, в якому б урегульовувались питання господарської відповідальності. У зв'язку з цим провідне місце у регулюванні господарських договірних зобов'язань, у тому числі питань, пов'язаних із господарською відповідальністю за неви- 
конання чи неналежне виконання господарських договорів, віднесено до Цивільного кодексу Польщі.

Укладаючи господарські договори за законодавством Польщі, можна передбачити такі господарські санкції, як штраф і пеня. Польський законодавець чітко розрізняє, що у разі невиконання або неналежного виконання негрошового зобов'язання сплачується штраф, натомість у разі грошового зобов'язання - пеня.

У польському праві під штрафом необхідно розуміти грошову суму, яку боржник зобов'язаний сплатити за невиконання або неналежне виконання зобов'язання негрошового характеру (ст. 483 § 1 ЦК Польщі) [8]. Так, по-перше, як випливає з визначення, штраф являє собою певну грошову суму, яку зобов'язаний сплатити боржник, тобто, укладаючи договір, сторони можуть визначити конкретну грошову суму, наприклад 10000 злотих за неналежне виконання робіт. Однак на практиці також має місце відсоткове встановлення розміру штрафу, наприклад 1,5\% від вартості недопоставленої або неналежної якості поставленої продукції. Штраф також може бути застосований у разі, якщо сторона відмовиться від договору.

По-друге, штраф сплачується у разі невиконання або неналежного виконання негрошового зобов'язання, тобто штрафом можна забезпечити будь-яке зобов'язання, крім грошового.

По-третє, штраф сплачується за невиконання або неналежне виконання зобов'язання за наявності вини боржника, тобто застосовується у разі виникнення обставин, за які зобов'язана сторона несе відповідальність. Тому, наприклад, у разі, якщо субпідрядник спізнюється з виконанням будівельних робіт у зв'язку з несвоєчасною поставкою будівельних матеріалів генеральним підрядчиком або з огляду на несприятливі кліматичні умови, і зобов'язання у зв'язку з цим не може бути виконане своєчасно, його не може бути притягнуто до відповідальності у разі настання таких обставин. 3 огляду на зазначене, сторони у договорі можуть визначити обставини, за яких до іншої сторони не буде застосовано відповідальності у вигляді штрафу. Таким чином, сплачувати штраф зобов'язана тільки та сторона договору, яка неналежним чином виконала договір зі своєї вини.

По-четверте, штраф має виконувати своєрідну компенсаційну функцію на випадок невиконання або неналежного виконання договору. При цьому штраф можна вимагати, в принципі, незалежно від того, чи були нанесені збитки чи ні, і якщо так, то незалежно від їх розміру [9, с. 36-37].
По-п'яте, відповідно до ст. 484 § 2 ЦК Польщі, розмір встановленого в договорі штрафу може бути зменшено, але таке зменшення може відбутись лише на підставі рішення суду. Суд може зменшити розмір штрафу тільки за таких передумов: 1) договір виконано в значній частині; чим більший ступінь виконання договору, тим на більшу суму суд може зменшити штраф; 2) штраф у договорі є значно завищений стосовно збитків, які може зазнати кредитор; 3) кредитор своїми діями вплинув на неналежне виконання або невиконання договору (наприклад, якщо підрядник і субпідрядник встановили в договорі штраф за несвоєчасне виконання робіт і підрядник несвоєчасно поставив матеріали, то субпідрядник може вимагати зменшення розміру штрафу) [10, с. 299-301].

Таким чином, застосування штрафу в господарських договорах, зокрема встановлення його розміру, хоча і відбувається за погодженням сторін, але може бути зменшене судом.

У разі несвоєчасного виконання грошових зобов'язань у польському праві застосовується пеня. Відповідно до ст. 481 ЦК Польщі, якщо боржник несвоєчасно виконує грошове зобов'язання, кредитор може вимагати відсотки за час прострочення, навіть якщо не зазнав жодної шкоди і навіть якщо прострочення було наслідком обставин, за які боржник не несе відповідальності.

Крім вищевказаних положень ЦК Польщі, права кредитора і обов'язки боржника у зв'язку з термінами оплати у разі проведення господарських операцій регулюються Законом «Про терміни оплати в торгових операціях» від 08.03.2013. Відповідно п. 3 ст. 4 зазначеного Закону законодавчими відсотками за несвоєчасне проведення розрахунків у господарських операціях є відсотки в розмірі, що дорівнює ставці рефінансування Нацбанку Польщі і вісім процентних пунктів [11]. Розмір даної ставки встановлюється два рази на рік - на I й II півріччя (в I півріччі 2019 року становить 9,5\%).

Якщо сторони не передбачили в договорі термін оплати, кредитор може вимагати сплати пені після закінчення 30 днів, починаючи з дня виконання ним зобов'язання до дня проведення належної оплати (п. 1 ст. 6). Закон визначає, що термін оплати, зазначений у договорі, не може перевищувати 60 днів, рахуючи з дня передачі боржникові фактури чи рахунку, що підтверджують поставку товару або виконання робіт (надання послуг), якщо сторони в договорі не домовилися про інше і за умови, що таке положення не є дискримінацією по відношенню до кредитора. 
Пеня розраховується шляхом множення величини заборгованості на кількість днів прострочення виконання зобов'язання і множенням на розмір законодавчо визначеної відсоткової ставки і діленням на 365 днів.

Крім цього, згідно 3 п. 1 ст. 10 Закону кредитор, починаючи з дати отримання права на нарахування пені, має право на оплату боржником суми 40 євро в перерахунку на польську валюту за середнім курсом євро, оголошеним Національним Банком Польщі в останній робочий день місяця, що передує місяцю, в якому настало право вимоги. Така оплата є компенсацією за витрати, пов'язані зі стягненням заборгованості, якщо вартість понесених витрат $€$ вищою, ніж зазначена сума, можна додатково вимагати вартість перевищення понесених витрат.

Якщо сторони в договорі виключать або обмежать права кредитора чи зобов'язання боржника щодо сплати пені (наприклад, кредитор у договорі відмовиться від пені, або зобов'язується іiї не доводити в судовому порядку, або звільняе боржника від обов’язку платити пеню), такі положення договору будуть вважатися недійсними. Також недійсними будуть положення договору, які будуть визначати пеню в розмірі, нижчому за законодавчо визначений.

\section{Висновки}

Проведений аналіз законодавчих актів і наукової літератури з питань регулювання штрафних санкцій за українським та польським законодавством дає підстави стверджувати, що український законодавець відніс до них неустойку, штраф і пеню, що регулюються положеннями ГКУ і ЦКУ, натомість польський законодавець передбачив застосування таких господарських санкцій, як штраф і пеня, що регулюються ЦК Польщі. Укладаючи зовнішньоекономічні договори за участю суб’єктів господарювання України та Польщі, необхідно врахувати наявні розбіжності щодо видів штрафних санкцій і порядку їх застосування. Загалом, щодо укладення зовнішньоекономічних договорів необхідно звернути увагу, що штраф стягується за невиконання або неналежне виконання господарського зобов'язання в польському праві негрошового характеру, в Україні такі обмеження відсутні. Польський законодавець передбачив сплату пені у разі несвоєчасного про- ведення грошових розрахунків у договірних відносинах, в Україні допускається застосування пені також до інших зобов'язань. Поняття неустойки взагалі відсутнє в господарському праві Польщі. Отже, укладаючи зовнішньоекономічний договір, сторони мають максимально передбачити підстави застосування штрафних санкцій і їхній розмір, інакше застосування цих санкцій буде неможливим.

\section{Список використаних джерел:}

1. Про затвердження Положення про форму зовнішньоекономічних договорів (контрактів) : наказ Міністерства економіки та 3 питань європейської інтеграції України від 06 вересня 2001 p. № 201. URL: https://zakon.rada.gov.ua/ laws/show/z0833-01

2. Господарський кодекс України : Закон України від 16 січня 2003 р. № 436-IV. Відомості Верховної Ради України. 2003. № 18, № 19-20, № 21-22. Ст. 144.

3. Цивільний кодекс України : Закон України від 16 січня 2003 р. № 435-IV. Відомості Верховної Ради Украӥни. 2003. №№ 40-44. Ст. 356.

4. Татькова 3. Відповідальність у формі сплати штрафних санкцій. Науковий вісник Ужгородського університету. Серія «Право». 2011. Випуск 15. С. 37-43.

5. Про несвоєчасне виконання грошових зобов'язань : Закон України від 22 листопада 1996 р. № 543/96-ВР. Відомості Верховної Ради Украӥни. 1997. № 5. Ст. 28.

6. Черешнюк В. М. Правове регулювання укладення і виконання господарських договоpiв : автореф. дис. на здобуття наук. ступеня канд. юрид. наук : спец. 12.00 .04 «Господарське право; господарсько-процесуальнеправо».Київ, 2007.19с.

7. Науково-практичний коментар Господарського кодексу України / за заг. ред. Г. Л. Знаменського, В. С. Щербини; кол. авт.: О.А. Беляневич, О.М.Вінник, В. С. Щербина та ін. Київ : Юрінком Інтер, 2008. $720 \mathrm{c}$.

8. Kodeks cywilny : ustawa z dnia 23 kwietnia 1964 r. Dziennik Ustaw. 1964. Nr 16. Poz. 93.

9. Szumańska Joanna. Nadmierne odszkodowanie z tytułu kary umownej - overcompensatory remedy. Rynek - Spoleczeństwo - Kultura. 2016. Nr Specjalny S. 3-42.

10. Szewczyk Jarosław. O kryteriach miarkowania nadmiernych kar umownych w kontekście orzecznictwa Sąu Najwyższego. Palestra. 2013. Nr 1-2. S. 298-304.

11. O terminach zapłaty $\mathrm{w}$ transakcjach handlowych : ustawa z dn. 8 marca 2013 r. Dziennik Ustaw. 2013. Poz. 403. 
В статье исследуются нормативно-правовые и практические аспекты применения штрафных санкций в сфере хозяйствования согласно законодательству Украины и Польши. Проведенный анализ дает основания утверждать, что и в украинском, и в польском законодательстве за невыполнение или ненадлежащее выполнение хозяйственных обязательств применяются штрафные санкиии. Сделан взвод относительно сходства подходов в законодательстве двух государств относительно применения штрафных санкций, к которым отнесены штраф и пеня, за исключением неустойки, которая предусмотрена только в законодательстве Украинь.

Ключевые слова: неустойка, штраф, пеня, внешнеэкономический договор, невыполнение и ненадлежащее выполнение хозяйственных обязательств.

The article outlines the legal and practical aspects of the application of penal sanctions in the field of economic activity under the legislation of Ukraine and Poland. Further analysis showed that both Ukrainian and Polish legislation impose penalties for non-fulfillment or improper fulfilment of economic obligations. The findings of this study indicate similarity of approaches in the legislation of the two states regarding the application of penalties, which include a fine and a penalty for each day of delay (payment or fulfilment of the obligation), with the exception of a forfeit that is used only in the legislation of Ukraine.

Key words: forfeit, fine, penalty for each day of delay, foreign economic agreement, non-fulfillment and improper fulfilment of economic obligations. 